\title{
ANALISIS MULTIRESOLUSI WAVELET DENGAN TRANSFORMASI WAVELET DISKRIT BERB ASIS GUI R (STUDI KASUS: INFLASI DI INDONESIA PADA PERIODE OKTOBER 2007-MEI 2018)
}

\author{
Sania Anisa Farah ${ }^{1}$, Suparti ${ }^{2}$, Dwi Ispriyanti ${ }^{3}$ \\ 1,2,3 Departemen Statistika, Fakultas Sains dan Matematika, Universitas Diponegoro \\ e-mail :suparti702@gmail.com
}

\begin{abstract}
Lately, the wavelet applications are widely used in statistics, one of themis discrete wavelet transform(DWT) which is a non-parametric method for signal analysis, data compression, and time series analysis. As technology becomes more advanced, a software is necessary to support the statistical analysis by such method, one of thembeing the open source based R. It is often used in statistical computing with command line interface (CLI) which requires the R user to remember the names of syntaxes and functions. It becomes less effective when there are many related statistical analysis involved, so graphical user interface (GUI) is needed to access all of themeasily. The testing of multires olution analysis by DWT for Haar, Daublets, and Coiflets filters with levels 1-6 had been performed by using the inflation data in Indonesia during October 2007-May 2018 taken from Bank Indonesia website. The res ult shows that the sixth level of DWT gives the bestestimation for each filters, and Daublets 20 is the best filter for overall estimation with MSE, MAPE, and MASE values are $0.05755,3.40678$, and 0.35343 respectively. The packages for GUI construction in R are wavelets and shiny. Based on its usage, the GUI is capable of processing the chosen analysis and showing the valid output.
\end{abstract}

Keywords: Discrete Wavelet Transform(DWT), The Pyramid Algorithm, Multiresolution Analysis (MRA), R, Graphical User Interface (GUI)

\section{PENDAHULUAN}

Inflasi merupakan suatu proses meningkatnya harga-harga secara umum dan terus menerus. Tingkat kenaikannya dapat diukur dengan berbagai indikator, beberapa di antaranya adalah Indeks Harga Konsumen (IHK), Indeks Harga Perdagangan Besar (IHPB), Indeks Harga Produsen (IHP), Deflator Produk Domestik Bruto (PDB), dan Indeks Harga Aset. Indikator-indikator ini berubah dari waktu ke waktu sehingga data inflasi termasuk dalam data runtun waktu. Ada banyak metode untuk menganalisis data seperti ini, salah satunya adalah transformasi wavelet.

Wavelet diperkenalkan sejak tahun 1980-an hingga awal tahun 1990-an yang awalnya wavelet populer sebagai literatur untuk analisis gelombang. Seiring berkembangnya ilmu pengetahuan, wavelet berkembang di berbagai cabang ilmu statistika seperti analisis ketahanan hidup (analisis survival), analisis runtun waktu, analisis regresi, dan stabilis asi variansi (Nason, 2008). Transformasi wavelet yang dapat digunakan terbagi menjadi dua, yaitu transformasi wavelet kontinu (Continuous Wavelet Transform / CWT) dan transformasi wavelet diskrit (Discrete Wavelet Transform / DWT). Transformasi wavelet diskrit digunakan dalam kasus ini karena dapat memetakan data dari domain data asli ke domain wavelet. Selain itu, penggunaan DWT dapat disandingkan dengan analisis multiresolusi wavelet (Multiresolution Analysis / MRA) untuk mengetahui kemulusan estimasi data.

Seiring perkembangan teknologi, tentunya diperlukan alat yang menunjang kebutuhan analisis statistika yaitu menggunakan software yang sudah banyak dibuat untuk keperluan tersebut, salah satunya adalah $\mathrm{R}$ yang berbasis open source. Ada dua bentuk umum antarmuka pengguna dalam komputasi statistika pada $\mathrm{R}$ yaitu Command Line Interface (CLI) dan Graphical User Interface (GUI). CLI biasanya terdiri dari sebuah konsol tekstual dimana pengguna mengetikkan serangkaian perintah dalam bentuk teks, sedangkan GUI merupakan suatu media virtual dimana pengguna menggunakan ikon dan gambar pada 
layar untuk memasukkan perintah yang diinginkan. Antarmuka ini berdasarkan pada paradigma WIMP (window, icon, menu, dan pointer) (Penners, 2005).

Penggunaan R untuk metode wavelet khususnya untuk analisis multiresolusi wavelet masih menggunakan CLI dalam $\mathrm{R}$ console. Artinya pengguna $\mathrm{R}$ harus mengingat nama fungsi dan sintaks yang diperlukan. Hal ini dirasa kurang efektif jika dalam penggunaannya terdapat banyak analisis statistika sehingga GUI diperlukan untuk memudahkan pengguna dalam mengakses semua analisis yang akan digunakan. Berdasarkan hal tersebut, penulis akan membuat antarmuka berupa GUI bagi pengguna $\mathrm{R}$ dalam keperluan analisis multiresolusi wavelet dengan DWT dengan studi kasus inflasi di Indonesia periode Oktober 2007-Mei 2018.

\section{TINJAUAN PUSTAKA}

\subsection{Inflasi}

Secara sederhana inflasi diartikan sebagai meningkatnya harga-harga secara umum dan terus menerus. Kenaikan harga dari satu atau dua barang saja tidak dapat disebut inflasi kecuali bila kenaikan itu meluas (atau mengakibatkan kenaikan harga) pada barang lainnya. Beberapa indikator inflasi yang digunakan adalah Indeks Harga Konsumen (IHK), Indeks Harga Perdagangan Besar (IHPB), Indeks Harga Produsen (IHP), Deflator PDB, dan Indeks Harga Aset.

\subsection{Fungsi Wavelet}

Fungsi wavelet adalah suatu fungsi matematika yang mempunyai sifat-sifat tertentu di antaranya berosilasi di sekitar nol (seperti fungsi sinus dan cosinus) dan terlokalisasi dalam domain waktu artinya pada saat nilai domain relatif besar, fungsi wavelet berharga nol (Percival dan Walden, 2000). Fungsi wavelet dibedakan atas dua jenis, yaitu wavelet ayah $(\phi)$ dan wavelet ibu $(\psi)$ yang mempunyai sifat:

$$
\int_{-\infty}^{\infty} \phi(x) d x=1 \text { dan } \int_{-\infty}^{\infty} \psi(x) d x=0
$$

Dengan dilatasi diadik dan translasi integer, wavelet ayah dan wavelet ibu melahirkan keluarga wavelet yaitu:

$$
\phi_{j, k}(x)=2^{j / 2} \phi\left(2^{j} x-k\right) \text { dan } \psi_{j, k}(x)=2^{j / 2} \psi\left(2^{j} x-k\right)
$$

Indeks dilatasi $\mathrm{j}$ akan berpengaruh terhadap perubahan support dan daerah hasil (range) secara berkebalikan, artinya jika support menyempit maka range akan melebar. Indeks translasi $\mathrm{k}$ berpengaruh terhadap pergeseran posisi wavelet pada sumbu datar tanpa mengubah lebar support. Support suatu fungsi adalah closure dari himpunan titik-titik domain yang memberikan nilai fungsi tidak sama dengan nol (Simatupang dkk., 2014).

\section{Definisi 1}

Didefinisikan $f \in L^{2}[a, b]$ dengan $L^{2}[a, b]=\left\{f: \int_{a}^{b} f(x)^{2} d x<\infty\right\}$. Dua fungsi $f_{1}, f_{2} \in$ $L^{2}[a, b]$ dikatakan ortogonal jika $\left\langle f_{1}, f_{2}\right\rangle=0$ dengan hasil kali dalam $\left\langle f_{1}, f_{2}\right\rangle=$ $\int_{a}^{b} f_{1}(x) f_{2}(x) d x$ (Ogden, 1997).

\section{$\underline{\text { Definisi } 2}$}

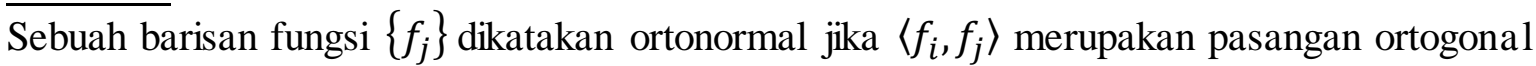
untuk setiap $\mathrm{i} \neq \mathrm{j}$ dan $\left\|f_{j}\right\|=1$ untuk semua $\mathrm{j}$ dengan $\left\|f_{j}\right\|=\sqrt{\left\langle f_{j}, f_{j}\right\rangle}=\sqrt{\int_{a}^{b} f_{j}^{2}(x) d x}$ (Ogden, 1997). 
Berikut adalah beberapa jenis wavelet ortogonal yang telah dikenal.

Tabel 1. Beberapa Jenis Wavelet yang Telah Dikenal

\begin{tabular}{|c|c|}
\hline Tipe & Nama Wavelet \\
\hline Haar & "haar" \\
\hline Daublets & “d4" “d6” “d8” “d10” “d12” “d14” “d16” “d18” “d20” \\
\hline Symmlets & “s4" “s6” “s8” “s10” “s12” “s14” “s16” “s18” “s20” \\
\hline Coiflets & “c6" "c 12" "c24" "c30” \\
\hline
\end{tabular}

Huruf pertama dari wavelet mengindikasikan nama, yaitu d untuk daublet, s untuk symmlet, dan c untuk coiflet. Nomor dari wavelet mengindikasikan panjang support (width) dan kehalusan (smoothness). Wavelet dengan nomor besar seperti d20 atau c30 relatif lebar dan halus, sedangkan wavelet dengan nomor kecil seperti d4 atau c6 kurang halus dan lebih sempit.

Dengan mengambil $\mathrm{J}$ cukup besar, representasi fungsi dalam wavelet dapat didekati dengan

$$
\begin{gathered}
f^{J}(x)=\sum_{k \in Z} c_{j_{0}, k} \phi_{j_{0}, k}(x)+\sum_{j=j_{0}}^{J-1} \sum_{k \in Z} d_{j, k} \psi_{j, k}(x) \\
\operatorname{dimana} c_{j_{0}, k}=\left\langle f, \phi_{j_{0}, k}\right\rangle \text { dan } d_{j, k}=\left\langle f, \psi_{j, k}\right\rangle .
\end{gathered}
$$

\subsection{Analis is Multiresolusi (Multiresolution Analysis / MRA)}

Didefinisikan sebuah ruang fungsi $V_{j}, j \in Z$ yakni $V_{j}=\left\{f \in L^{2}(R): f\right.$ adalah fungsi konstan sepotong-sepotong pada $\left.\left.\mid k 2^{-j},(k+1) 2^{-j}\right), k \in Z\right\}$.

Analisis multiresolusi $L^{2}(R)$ adalah ruang bagian tertutup $\left\{V_{j}, j \in Z\right\}$ yang memenuhi

1. $\quad \ldots \subset V_{-2} \subset V_{-1} \subset V_{0} \subset V_{1} \subset V_{2} \subset \ldots$

2. $\cap_{j \in Z} V_{j}=\{0\}, \bar{\cup}_{j \in Z} V_{j}=L^{2}(R)$

3. $f \in V_{j} \Leftrightarrow f(2.) \in V_{j+1}$

4. $f \in V_{0} \Rightarrow f(.-k) \in V_{0}, \forall k \in Z$

5. Terdapat sebuah fungsi $\phi \in V_{0}$ sehingga $\left\{\phi_{0, k}=\phi(.-k), k \in Z\right\}$ membentuk basis ortonormal untuk $\mathrm{V}_{0}$ dimana untuk semua $j, k \in Z, \phi_{j, k}(x)=2^{j / 2} \phi\left(2^{j} x-k\right)$.

\subsection{Transformasi Wavelet Diskrit (Discrete Wavelet Transform / DWT)}

Data dinyatakan dengan $n=2^{J}$ dan didekomposisikan ke dalam koefisien wavelet $(W)$ dan koefisien skala $(V)$. Pada koefisien DWT di level pertama berukuran $\frac{n}{2} \times 1$, untuk level kedua ukurannya $\frac{n}{4} \times 1$, sampai di level terakhir diperoleh $W_{j_{0}}$ dan $V_{j_{0}}$ didapatkan koefisien DWT dengan ukuran $\frac{n}{2^{J-1}} \times 1$ sehingga ketika dijumlahkan dari level pertama diperoleh matriks dengan ukuran $n \times 1$ sebagaimana ukuran data asli.

DWT dari sebuah deret waktu $\mathbf{X}$, dengan panjang $n$, adalah sebuah transformasi linear, dengan pembentukan $\boldsymbol{W}$ dari koefisien DWT per-level, dari perkalian matriks filter atas $\mathbf{X}$ adalah sebagai berikut:

$$
\mathcal{W}_{J} \boldsymbol{X}=\left[\begin{array}{c}
\mathcal{H}_{1} \\
\mathcal{H}_{2} \\
\vdots \\
\mathcal{H}_{J} \\
\mathcal{G}_{J}
\end{array}\right] \boldsymbol{X}=\left[\begin{array}{c}
\boldsymbol{W}_{1} \\
\boldsymbol{W}_{2} \\
\vdots \\
\boldsymbol{W}_{J} \\
\boldsymbol{V}_{J}
\end{array}\right]=\boldsymbol{W}
$$

$\mathcal{H}_{j}$ adalah matriks berukuran $\frac{n}{2^{j}} \times n$, dan $\mathcal{G}_{j}$ adalah matriks berukuran $1 \times n$. $\boldsymbol{W}_{j}$ adalah vektor kolom dengan panjang $\frac{n}{2^{j}}$ dan $\boldsymbol{V}_{J}$ adalah elemen terakhir dari $\boldsymbol{W}$. 


\subsection{Software $\mathbf{R}$ dan RStudio}

$\mathrm{R}$ merupakan salah satu software yang digunakan untuk keperluan komputasi statistika yang berbasis open source. Salah satu keunggulan dari software ini adalah banyaknya pilihan analisis statistika yang tersedia dalam bentuk paket R. Versi awal $\mathrm{R}$ dibuat pada tahun 1992 oleh Robert Gentleman dan Ross Ihaka di Universitas Auckland, New Zealand, dan versi R terbaru saat ini adalah R versi 3.4.4 (http://www.r-project.org/).

RStudio merupakan salah satu software yang dirancang untuk mempermudah penggunaan $\mathrm{R}$ yang mempunyai fitur yang tidak ada dalam $\mathrm{R}$, beberapa di antaranya adalah koreksi penulisan sintaks dan fitur bantuan (help) yang terintegrasi dalam RStudio. Software ini mempunyai dua versi, yaitu RStudio Desktop yang merupakan versi dasar dari RStudio dan RStudio Server yang dapat diakses melalui peramban web yang terhubung dengan suatu jaringan komputer.

\subsection{Paket R shiny}

Paket shiny dikembangkan oleh pengembang RStudio untuk membuat aplikasi GUI hanya dengan bermodalkan R. Pengguna dapat mengintegrasikan HTML, CSS, atau JavaScript dalam aplikasi yang dibuat, tetapi ketiganya bukan merupakan prasyarat untuk menggunakan paket ini. Aplikasi yang dibuat dengan paket shiny dapat dijalankan pada peramban web baik melalui $\mathrm{R}$ itu sendiri maupun melalui server RStudio (https://shiny.rstudio.com/deploy/).

Pembuatan aplikasi GUI dengan paket shiny memerlukan tiga komponen utama, yaitu obyek UI untuk mengatur tampilan aplikasi, fungsi server untuk mendefinisikan program inti dari aplikasi tersebut, dan fungsi shinyApp untuk menjalankan aplikasi dari komponen server dan UI yang sudah didefinisikan sebelumnya. Ketiga komponen tersebut disatukan dalam sebuah file $\mathrm{R}$ yang bernama app. $\mathrm{R}$ dengan format sebagai berikut:

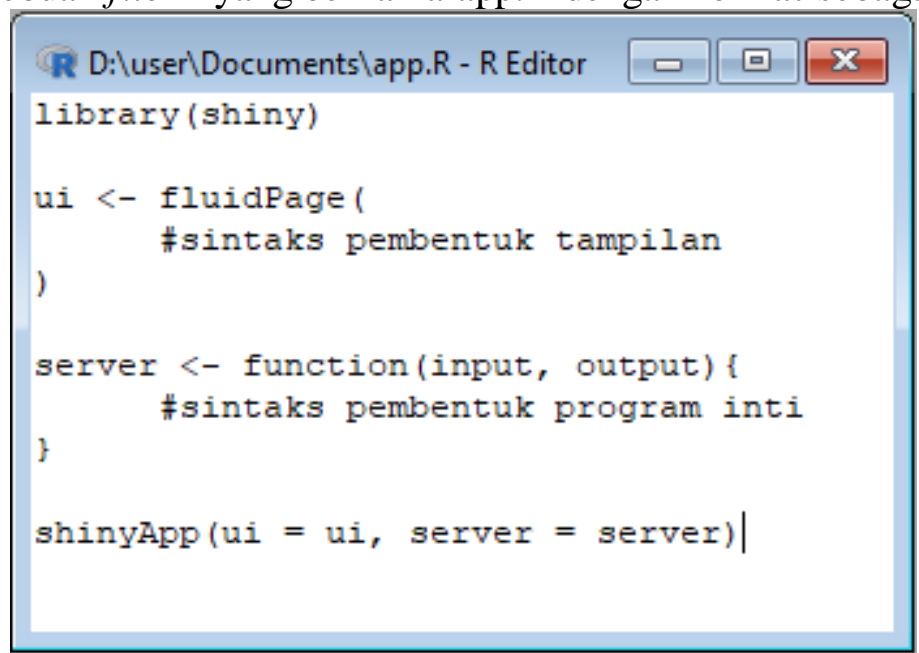

Gambar 1. Sintaks Dasar dalam Aplikasi shiny

\subsection{Mean Square Error (MSE)}

Mean Square Error (MSE) merupakan salah satu metode untuk mengukur tingkat keakuratan suatu model peramalan. Nilai ini merepresentasikan rata-rata dari kesalahan (error) yang dikuadratkan. Secara matematis nilai MSE didefinisikan sebagai

$$
\operatorname{MSE}=\frac{1}{n} \sum_{i=1}^{n} e_{i}^{2}=\frac{1}{n} \sum_{i=1}^{n}\left(y_{i}-\hat{y}_{i}\right)^{2}
$$

dimana $y_{i}$ merupakan nilai aktual dan $\hat{y}_{i}$ merupakan nilai prediksi. Untuk analisis multiresolusi wavelet $\hat{y}_{i}$ dan $e_{i}$ adalah komponen proyeksi $(S)$ dan jumlahan dari semua 
komponen detail $(D)$ dari MRA secara berurutan. Semakin kecil nilai MSE yang dihasilkan, semakin baik pula model yang digunakan.

\subsection{Mean Absolute Percentage Error (MAPE)}

Mean Absolute Percentage Error (MAPE) merupakan suatu metode untuk mengukur akurasi dari suatu peramalan dengan menghitung rata-rata dari keseluruhan persentase kesalahan (selisih) antara data aktual dengan data hasil peramalan. Ukuran akurasi dicocokkan dengan data time series, dan ditunjukkan dalam persentase. Secara matematis nilai MAPE didefinisikan sebagai

$$
\text { MAPE }=\frac{1}{n} \sum_{i=1}^{n}\left|\frac{y_{i}-\hat{y}_{i}}{y_{i}}\right| 100 \%
$$

Metode ini mempunyai beberapa kelemahan (Tofallis, 2015), di antaranya:

a. Tidak dapat digunakan jika ada data dengan nilai nol karena hasilnya akan dibagi dengan nol.

b. Tidak ada batas atas persentase error untuk hasil peramalan yang terlalu tinggi.

\subsection{Mean Absolute Scaled Error (MASE)}

Mean Absolute Scaled Error (MASE) merupakan suatu metode untuk mengukur akurasi dari suatu peramalan yang dikembangkan oleh Hyndman dan Koehler (2006). Metode ini dapat menjadi salah satu alternatif dari MAPE untuk mengatasi masalah yang ditimbulkannya. Secara matematis nilai MASE didefinisikan sebagai

dengan

$$
\operatorname{MASE}=\frac{1}{n} \sum_{i=1}^{n}\left(\frac{\left|e_{i}\right|}{q}\right)=\frac{1}{n q} \sum_{i=1}^{n}\left|y_{i}-\hat{y}_{i}\right|
$$

$$
q=\frac{1}{n-1} \sum_{i=2}^{n}\left|y_{i}-y_{i-1}\right|
$$

Seperti halnya MSE dan MAPE, semakin kecil nilai MASE yang dihasilkan, semakin baik pula model yang digunakan.

\section{METODE PENELITIAN}

3.1. Jenis dan Sumber Data

Data yang digunakan adalah data sekunder yang diperoleh dari situs Bank Indonesia (https://www.bi.go.id/id/moneter/inflasi/data). Data tersebut merupakan data runtun waktu dari inflasi di Indonesia berdasarkan perhitungan inflasi tahunan periode Oktober 2007-Mei 2018 dengan jumlah data sebanyak 128.

\subsection{Metode Analisis}

Adapun langkah-langkah dalam pelaksanaan peneltian dan analisis data yaitu diawali dengan menentukan data yang akan digunakan, dilanjutkan dengan mengidentifikasi analis is multiresolusi wavelet yang sesuai dengan kriteria data. Langkah selanjutnya yaitu mengidentifikasi hal-hal yang dibutuhkan dalam pembuatan GUI termasuk di dalamnya proses kerja GUI saat dijalankan, yaitu input, proses, dan output. Kemudian membuat GUI dengan menggunakan software $\mathrm{R}$ dan melakukan analisis multiresolusi wavelet menggunakan GUI yang telah dibuat sehingga output dari analisis dapat ditampilkan.

\section{HASIL DAN PEMBAHASAN}

\subsection{Pendekatan MRA pada DWT}

Analisis DWT didukung dengan MRA untuk kasus inflasi di Indonesia periode Oktober 2007-Mei 2018 dilakukan untuk mendapatkan pendekatan estimasi model asli yang 
optimal dalam level resolusi 1-6. Pendekatan MRA dilakukan dengan beberapa filter wavelet yaitu filter Haar, Daublets 4, 6, 8, 10, 12, 14, 16, 18 dan 20 serta Coiflets 6, 12, 18, 24 dan 30. Semua filter tersebut memberikan estimasi terbaik pada level resolusi keenam $(j=6)$ dengan nilai MSE, MAPE dan MASE sebagai berikut:

Tabel 2. Nilai MSE, MAPE dan MASE pada Level $j=6$ dari Semua Filter

\begin{tabular}{cccc}
\hline Filter & MSE & MAPE & MASE \\
\hline Haar & 0,14162 & 4,81468 & 0,56156 \\
Daublets 4 & 0,07039 & 3,70466 & 0,40121 \\
Daublets 6 & 0,06283 & 3,53523 & 0,36332 \\
Daublets 8 & 0,06891 & 3,57748 & 0,36650 \\
Daublets 10 & 0,07397 & 3,59037 & 0,38151 \\
Daublets 12 & 0,07350 & 3,67287 & 0,40629 \\
Daublets 14 & 0,06812 & 3,63673 & 0,40409 \\
Daublets 16 & 0,06131 & 3,55948 & 0,39127 \\
Daublets 18 & 0,05708 & 3,44661 & 0,36972 \\
Daublets 20 & 0,05755 & 3,40678 & 0,35343 \\
Coiflets 6 & 0,06775 & 3,59606 & 0,38298 \\
Coiflets 12 & 0,05930 & 3,45842 & 0,36437 \\
Coiflets 18 & 0,05812 & 3,46075 & 0,36536 \\
Coiflets 24 & 0,05769 & 3,45810 & 0,36627 \\
Coiflets 30 & 0,05744 & 3,44913 & 0,36617
\end{tabular}

Dari tabel 2 terlihat bahwa filter Daublets 18 memiliki nilai MSE terkecil, sedangkan filter Daublets 20 memiliki nilai MAPE dan MASE terkecil. Dalam kasus ini metode MASE digunakan sebagai indikator utama untuk mengukur akurasi dari estimasi data karena lebih akurat dari MSE dan dapat mengatasi masalah pada MAPE, sehingga dapat disimpulkan bahwa filter Daublets 20 memberikan estimasi terbaik untuk data inflasi di Indonesia periode Oktober 2007-Mei 2018.

\subsection{Persiapan dan Kebutuhan dalam Pembuatan GUI}

Sebelum membuat GUI, diperlukan proses identifikasi mengenai hal-hal apa saja yang diperlukan dalam GUI tersebut. Proses ini bertujuan untuk memahami hal-hal yang menjadi bagian dari antarmuka itu sendiri, antara lain input, proses dan output. Yang menja di input untuk GUI yaitu file data yang disimpan dalam bentuk ekstensi csv menggunakan software R dan Notepad. Sedangkan bagian proses dan output sepenuhnya menggunakan software $\mathrm{R}$ versi 3.4.3 (https://cran.r-project.org/) dan RStudio versi 1.1.456 (https://www.rstudio.com/). Adapun paket R yang diperlukan dalam pembuatan GUI ini yaitu shiny dan wavelets.

\subsection{Mendesain Tampilan Antarmuka GUI}

Setelah semua kebutuhan yang akan digunakan dalam membuat GUI tersedia, tahap selanjutnya adalah mendesain tampilan antarmuka dari GUI. Tampilan ini diatur dalam suatu obyek UI pada file app.R yang memuat penempatan widget, baik untuk memasukkan input maupun menampilkan output. Jika dijalankan bersama fungsi server dengan perintah shinyApp (ui $=u i$, server $=$ server), obyek UI akan memberikan tampilan seperti gambar 2. 


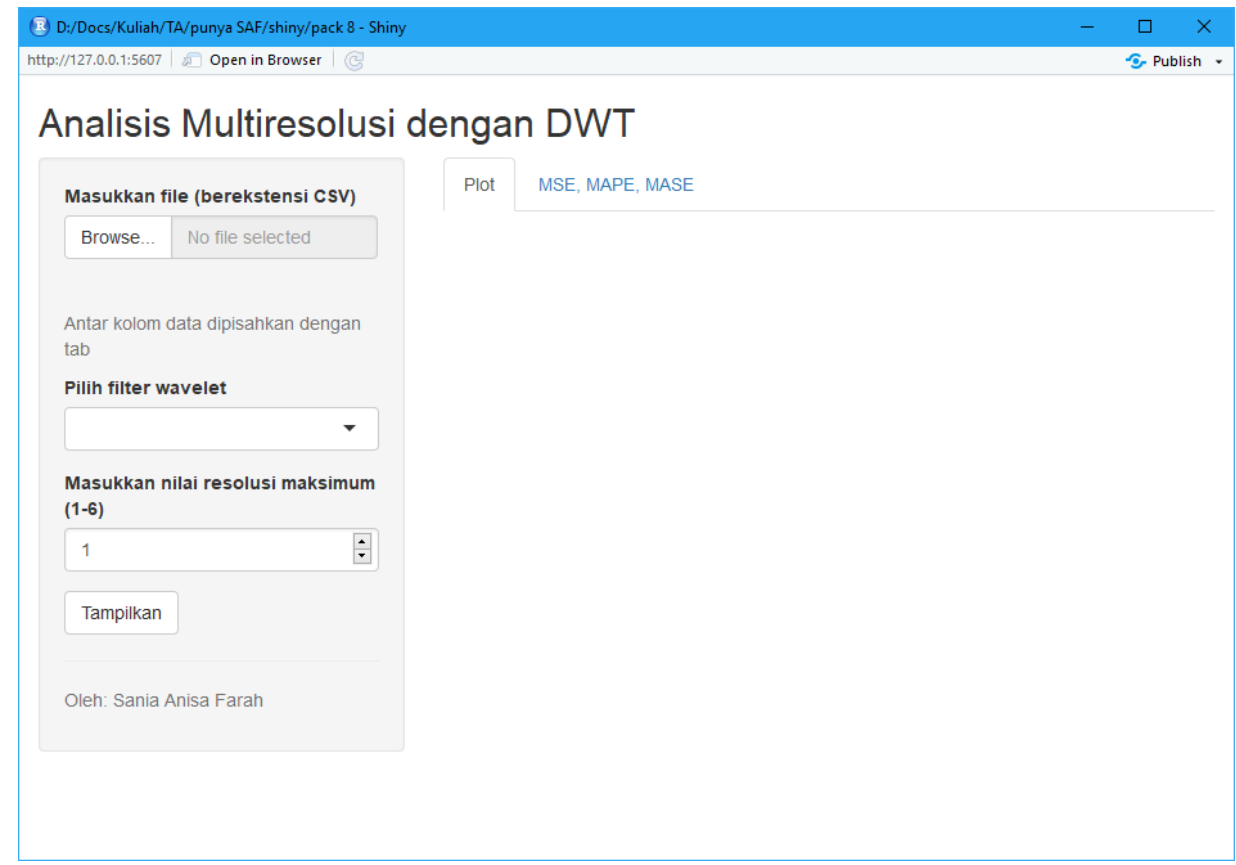

\section{Gambar 2. Jendela Utama GUI}

\subsection{Menyus un dan Menghubungkan Perintah dalam GUI}

Dalam pembuatan GUI ini, semua paket yang dibutuhkan terinstal secara online saat software RStudio dijalankan sehingga paket yang memiliki ketergantungan terhadap paket lainnya akan terunduh secara otomatis. Semua sintaks yang ada di GUI ini dibagi menjadi 5 file $\mathrm{R}$ dalam satu folder yang sama untuk memudahkan pengelompokan masing-masing sintaks.

Adapun semua proses dalam GUI, mulai dari impor data sampai menampilkan output, diatur dalam fungsi server pada file app.R. Jika tidak terdapat error pada salah satu file R yang digunakan, maka jendela utama GUI akan muncul seperti yang ditunjukkan pada gambar 2 saat fungsi server dijalankan bersama dengan obyek UI dengan perintah shinyApp (ui $=u i$, server $=$ server).

\subsection{Penggunaan dan Hasil dari GUI}

Ketika GUI siap untuk digunakan, selanjutnya mengimpor file data dengan ekstensi csv dan memilih filter dari pilihan filter yang tersedia. Impor file data dilakukan dengan mengeklik tombol "Browse" dan mencari file data yang dimaksud, sedangkan pemilihan filter dilakukan dengan memilih salah satu dari semua pilihan filter dalam select box pada panel samping. Sebagai contoh, akan dilakukan pendekatan MRA dari data inflasi di Indonesia periode Oktober 2007-Mei 2018 dengan filter Daublets 6 dan resolusi maksimum yang ditampilkan adalah 5. Output yang dihasilkan akan muncul dalam tab "Plot" dan "MSE, MAPE, MASE" sebagaimana ditunjukkan dalam gambar 3 dan 4 . 


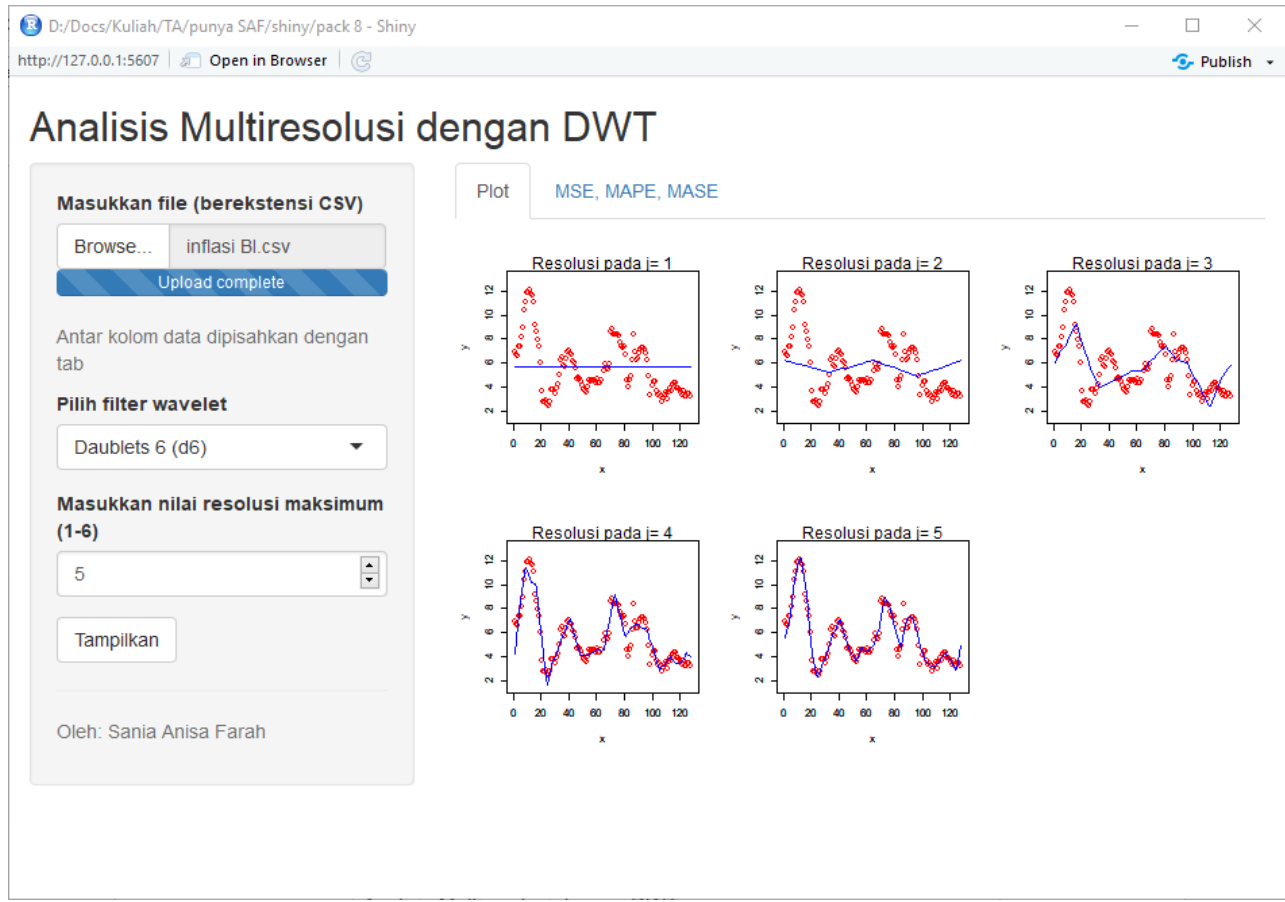

Gambar 3. Output pada Tab "Plot"

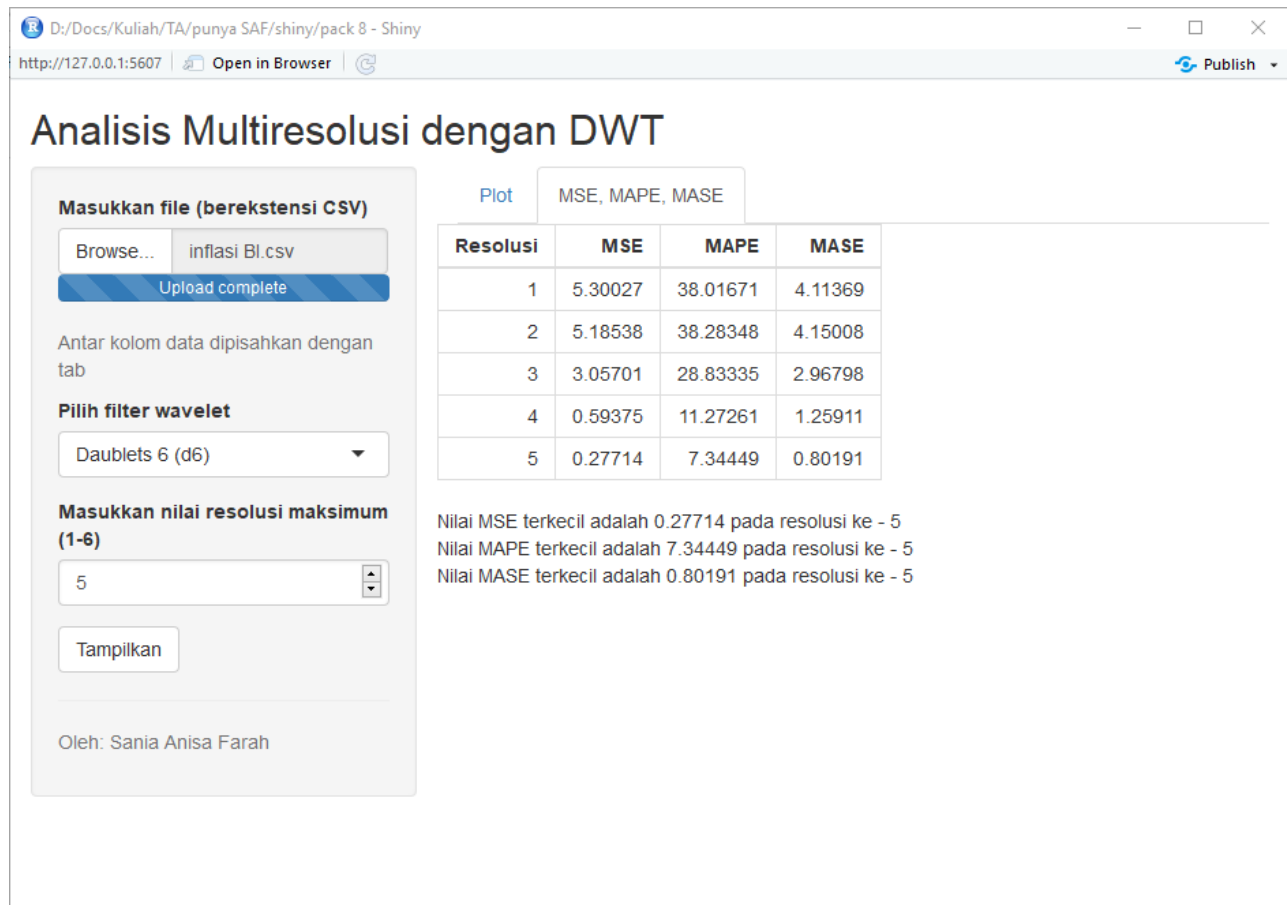

Gambar 4. Output pada Tab "MSE, MAPE, MASE"

\section{KESIMPULAN}

Dari hasil analisis dan pembahasan yang telah dilakukan, dapat diperoleh beberapa kesimpulan, yaitu:

1. Dari analisis data dengan pendekatan MRA pada DWT diperoleh estimasi terbaik pada level resolusi $j=6$ untuk masing-masing filter. Hal ini terlihat dari nilai-nilai 
MSE, MAPE dan MASE yang dihasilkan dengan melihat nilai-nilai terkecil dari masing-masing indikator pada masing-masing level resolusi. Sedangkan secara keseluruhan diperoleh estimasi terbaik pada filter Daublets 20 dengan level resolusi $j=6$.

2. Hasil pengujian data dengan pendekatan MRA pada DWT juga ditunjukkan dalam GUI yang telah dibuat dengan menampilkan output yang valid dari hasil penggunaannya. GUI ini memudahkan pengguna untuk melakukan analisis multiresolusi wavelet dengan DWT walaupun analisis yang tersedia dalam GUI masih terbatas.

\section{DAFTAR PUSTAKA}

Bank Indonesia. LAPORAN INFLASI (Indeks Harga Konsumen). https://www.bi.go.id/id/moneter/inflasi/data (diunduh 8 Juni 2018).

Hyndman, R. J. \& Koehler, A. B. 2006. Another Look at Measures of Forecast Accuracy. International Journal of Forecasting, Volume 22, Nomor 4, 679-688.

Nason, G.P. 2008. Wavelet Methods in Statistics with R. Springer. Bristol: University Walk.

Ogden, R.T. 1997. Essential Wavelet for Statistical Application and Data Analysis. Boston: Birkhauser.

Penners, R. GTK-WIMP (Windows Impersonator). http://gtk-wimp.sourceforge.net/ (diunduh 25 Februari 2018).

Percival, D.B. \& Walden, A.T. 2000. Wavelet Methods for Time Series Analysis. $1^{\text {st }}$ Published. New York: Cambridge University Press.

R. The R Projectfor Statistical Computing. http://www.r-project.org/ (diunduh 26 Februari 2018).

RStudio. Hosting and Deployment. https://shiny.rstudio.com/deploy/ (diunduh 8 Maret 2018).

Simatupang, E. D., Suparti, \& Rahmawati, R. 2014. Kajian Model Inflasi Tahunan Kota Sibolga dengan ARIMA dan Pendekatan Regresi Polinomial pada Analisis Multiresolusi Wavelet. Jurnal Gaussian, Volume 3, Nomor 2, 213-222.

Tofallis, C. 2015. A Better Measure of Relative Prediction Accuracy for Model Selection and Model Estimation. Journal of the Operational Research Society, Volume 66, Nomor 8, 1352-1362 